\title{
Attesting Representation through Power of Attorney: The Ethiopian Approach
}

\author{
DOI http://dx.doi.org/10.4314/mlr.v15i1.8
}

Tewodros Meheret *

\begin{abstract}
Agency is vital in modern life, and it is hardly effective without a power of attorney. However, it has not received sufficient attention in legal discourse commensurate with the legal requirements for its validity and its wide utilization. An agent is allowed to perform acts that have impact on the rights and obligations of another person usually through this instrument. This comment aims at examining the sporadic provisions in various laws which are relevant to the instrument so as to address issues which have legal as well as practical significance arising in the use of the instrument. In the absence of a law devoted to the instrument (and that takes its impact into account), it is obvious that more questions remain unanswered. An attempt is made to test the relevant laws in force with a view to establishing whether they live up to the expectations of the time.
\end{abstract}

\section{Key terms}

Agency $\cdot$ Power of Attorney $\cdot$ Authentication $\cdot$ Representation $\cdot$ Ethiopia

\section{Suggested citation:}

Tewodros Meheret (2021), 'Attesting Representation through Power of Attorney: The Ethiopian Approach', 15 Mizan Law Review 1: 227-262.

* Tewodros Meheret, Assistant Professor of Law, Addis Ababa University School of Law; Consultant and Attorney at Law Email: <tmeheret@yahoo.com>

ORCID: https://orcid.org/0000-0002-5190-0354

\section{Frequently used term}

Agency, where its usage so requires, refers to Federal Documents Registration Agency 


\section{Introduction}

People usually perform juridical acts by themselves directly enjoying the rights and discharging the obligations arising therefrom. They also engage another person to perform the acts on their behalf. In legal terms, representation means that a juridical act performed by one person is considered to be the act of another person. ${ }^{1}$ It may be obligatory or voluntary. The focus of this comment is voluntary representation which involves a power of attorney. It helps to bring up a relationship among three persons, the represented, the representative and the third party who deals with the representative. As a component of this relationship, a power of attorney has unilateral character as an authority conferred on an agent so that he/she can represent the principal in dealings with third parties. ${ }^{2}$

Power of attorney comes into the picture when one consensually confers power on another person for the performance of juridical acts. It is, therefore, a mechanism of making the internal relationship known to third parties. As a very vital tool in streamlining the needs of modern life, it allows mobility of people without abandoning their affairs and enables them to carry out multiple activities simultaneously.

The focus here is contractual agency which arises from a contract between the parties who willingly create the relationship. For the purpose of the internal relationship, agreement of the parties suffices but representation calls for a means of proving the fact or claim that one is acting on behalf of another. A power of attorney is one of the most used legal documents in Ethiopia while it is one of the most frequently used in international interactions. ${ }^{3}$ The relationships are internal and external, the agent being an intermediary. Agency becomes effective if an agent effectively concludes a contract on behalf of the principal that affects the rights and obligations of the latter. Allowing a person to do acts which entails such effects requires attestation of the delegation.

The law provides that "[w]hosoever has dealings with an agent may at any time require him to produce a justification of his authority and, where his

\footnotetext{
${ }^{1}$ B.A. Schuijling (2016), Representation, Power of Attorney and Mandate, in Jeroen Chorus, Ewoud Hondius \& Wim Voermans, Introduction to Dutch Law, Kluwer Law International B.V, p. 177

${ }^{2}$ See, for example, Phanor James Eder, Power of Attorney in International practice, $\mathrm{p}$. 859 available at http://scholarship.law.upenn.edu/cgi/viewcontent.cgi?article=8254\&context=penn_law _review, accessed on 15/7/2016

${ }^{3} \overline{\text { Ibid. }}$.
} 
authority is evidenced by a document, to produce a copy of such document duly signed by the agent". "It can be gathered from this rule that it is up to the third party to demand that the purported agent produce justification for this claim. Although the third party may agree to take the alleged status for granted potentially under the pain of losing the action against the principal, it is the duty of the agent to produce the evidence if the third party so demands. It is also implied in the law that such delegation may not necessarily be evidenced by a document, because we can have representation without a power of attorney.

In spite of the connotation that power of attorney is optional, it remains to be addressed whether delegation is possible without a power of attorney. Whether it is mandatory or optional, the form it takes should be known so that parties can be sure about the instrument they are utilizing. In this regard, it is imperative to ascertain whether it can be used without being authenticated given the fact that the law merely refers to a document by which authority is conferred. The correlation between power of attorney and contract of agency is also another point worth exploring. Further, examination is made as to how the authentication and legalization processes are done and how assessment is made to ensure reliability of the document. Determination and construction of its contents should be examined in order to grasp the substance of the instrument. An attempt is thus made to deal with these questions with a view to shedding light on the instrument in the absence of a special law devoted to answer them.

This comment examines the relevant laws with a view to establishing status, validity and appropriateness of the instrument in light of the requirements set by the law with respect to its form and contents. It is based on doctrinal research which tries to explore the law applicable to a power of attorney and its utilization looking into the manner of executing it. It raises the issue whether we can have agency without the instrument and how the instrument takes shape and effect. It relies on qualitative method so that the existing law is assessed against available standards and needs of the society. Practical application of the law is also scrutinized so as to measure its responsiveness and compatibility. Relevant court cases have been examined to illustrate the assertions made herein.

\footnotetext{
${ }^{4}$ Civil Code of Ethiopia Proclamation No. 165 of 1960 (herein after the Civil Code), Art. 2186.
} 


\section{Essence of a Power of Attorney}

Generally, it is assumed that a power of attorney is a document through which authority is conferred on another person. However, an observation made merely skimming through the relevant laws defies such simplicity. For instance, in some provisions of the Civil Code, the term power of attorney refers to a document ${ }^{5}$ while in others it denotes the authority conferred on the agent. ${ }^{6}$ As a third party may rely on the information given to him by the agent regarding the agency, ${ }^{7}$ delegation of authority may be granted without a document evidencing the same. On top of the provisions of the Civil Code, we can deduce from the pertinent provisions of Proclamation No. 922/2015 ${ }^{8}$ that the term stands for a document rather than the authority it evidences. ${ }^{9}$

Despite the equivocation in the laws, the definitions of the term leave no room for uncertainty that it refers to a document. It is defined as a legal document that allows a person, called the principal, to appoint someone to make decisions on behalf of the former. ${ }^{10}$ It is also defined as an instrument authorizing another to act as one's agent ${ }^{11}$ which can be in writing or other record by which power is granted. ${ }^{12}$ Thus, despite the doubt created by the prevarication in the Civil Code, based on the overwhelming authority

${ }^{5}$ See id. Art. 1640(b)

${ }^{6}$ See id. Arts. 2181, 2182, 2185(a) \&(b)

${ }^{7} I d$. Art. 2181(2). Without losing sight of the contention that there is no apparent agency in Ethiopia, it can be mentioned here that effect is given to such authorization.

${ }^{8}$ Authentication and Registration of Documents' Proclamation No. 922/2015, Federal Negarit Gazette, 22 ${ }^{\text {nd }}$ Year, No. 29, February 15, 2016 (herein after "Proclamation No. 922/2015" or "Proc. No. 922/2015")

${ }^{9}$ Article 2(1) of the Proclamation No. 922/2015 defines a document as a "contract, will, power of attorney, document or revocation translated from one language into another by a licensed translator, copy of a document, ... memorandum or/and articles of association, minutes or any written matter submitted for authentication and registration ..."; Article 9 of this proclamation lists documents which must be authenticated so that they can be valid, one of them being a power of attorney which is mentioned in sub article 1(b).

${ }^{10}$ Law Dictionary: http://thelawdictionary.org/article/how-to-revoke-power-ofattorney/\#ixzz2qhozfki6

${ }^{11}$ Black, Hennery Campbell, Black's Law Dictionary, 1393 (3rd ed. 1933).

12 Samuel A. Goldblatt (1951), Powers of Attorney in Foreign Countries, Washington University Law Review, Volume 1951, Issue 2, pp. 241-244; See Uniform Power of Attorney Act; In England, an instrument conferring authority by deed is termed a power of attorney. 
available, it can be concluded that the term 'power of attorney' refers to the document by which delegation is evidenced or in which it is recorded. ${ }^{13}$

One query that may be raised is whether a power of attorney is a sine qua non for agency or that such authorization can be considered as a power of attorney if it is supported by a document. Agency has three sources: a law, a contract and decision of a court. Generally, it is understood that a power of attorney evidences the delegation of authority one willingly confers on another. The underlying relationship is, therefore, a contract. ${ }^{14}$ In the case of contractual agency, a mechanism of proving that one is appointed by another is needed. The nature of the relationship and the source of authority are relevant to determine the manner in which the representation is to be effected.

When we have a power of attorney, obviously, there is a consensual relationship. It may be impugned whether a power of attorney necessarily presupposes a contractual relationship between the principal and the agent. Obviously, mere power of attorney does not give rise to a contractual relationship as it is a unilateral act. Its acceptance either expressly or impliedly, leads to a contractual relationship. ${ }^{15}$ Yet, in China Wanbo Engineering Corporation versus Workneh Mihrete, ${ }^{16}$ it has been decided that a power of attorney may not necessarily evidence the underlying relationship and it may be executed even where there is no direct relationship between the principal and the agent.

In that particular case the power of attorney was given by the applicant to the agent while the employment relationship (the latter had) was not with the applicant. The court held that a power of attorney cannot be used to establish

${ }^{13}$ Ethiopian law does not address the question whether the document is devoted to the purpose. It can be noted that delegation can be effected in documents which are meant for some other purposes. This is the case as regards a memorandum of association of a company in which the manager is delegated to represent the company. We have delegation through a document which, inter alea, is an instrument of delegation of authority. The question is whether such a document is a power of attorney.

${ }^{14}$ When a law or a court order is the sources of authority, the exercise of authority on behalf of another is undertaken by operation of the law or order of the court. There is no additional condition to be met and the fact giving rise to the representation (for instance, being a parent of a minor child) or appointment by a court suffices to establish the relationship.

${ }^{15}$ Civil Code, supra note 4, Article 2199 cum Article 2201.

${ }^{16}$ The applicant granted power of attorney to the agent as per the request of its retained lawyer. The designated agent sued the principal based on the power of attorney claiming that he is an employee. China Wanbo Engineering Corporation versus Workneh Mihrete, File No. 29866, Federal Supreme Court Cassation Decisions, Vol. 6, Ginbot 7, 2000 Ethiopian Calendar. 
employment relationship. The arrangement was that the lawyer retained by the applicant requested the latter to grant a power of attorney to the respondent and the former would handle everything else. Thus, even though a power of attorney was given, that cannot be used to evidence the relationship between a worker and an employer.

Although it was not at issue in the case, a question arises whether the relationship created can be characterized as a contract of agency. It was confirmed that the negotiation took place between the respondent and its lawyer. The role of the applicant was limited to executing the power of attorney to facilitate the arrangement proposed by the lawyer. This leads us to the query as to what will be the relationship between the applicant and the respondent. Obviously, the power of attorney gave rise to the agent-principal relationship as it has been handed over to the respondent who rendered the service thereafter. But was there a contract of agency?

The question may sound absurd as the respondent has become an agent and it must be captured by one of the sources of agency and under the circumstances, given the consensual nature of the relationship, contract is the appropriate source. Yet, the underlying relationship was between the lawyer and the respondent whereas we don't have sub-delegation or substituted agent here as the delegation was directly made by the principal. It is tenable to conclude that there is a contract of agency between the two parties ${ }^{17}$ in which the respondent renders the service to the applicant while the remuneration had to be paid by a third party.

A power of attorney by definition is an instrument through which one confers power on another to affect the rights of the former. In other words, it is through this instrument that delegation is made. There is no question on the depiction of such an instrument as a power of attorney though it remains to be explored whether a document is the only means of delegation. And yet, a document by which delegation is made does not become a power of attorney just because one is appointed to be an agent of another thereby. Rather, there are formal requirements which must be fulfilled so that delegation can be validly made which we examine below.

${ }^{17}$ It can be inferred from Article 2201(1) of the Civil Code that if an agent continues to act based on a power of attorney, it shall be implied that $\mathrm{s} /$ he has accepted the appointment. Hence, the simple fact that action has been taken based on a power of attorney by the person appointed by the principal constitutes the contractual relationship as the action amounts acceptance of the appointment. 


\section{Form}

As the acts to be done by the agent to bind the principal depend on its validity, it is pivotal to inquire whether the law sets forth special form and if so, as to the types of formality prerequisites for the validity of such a document. Questions arise whether the delegation should be incorporated in a document or not, and if it should be in written form whether it should be authenticated. If form is prescribed by the law, the manner in which it is to be evidenced and executed determine its validity and define its character. One may further ponder whether a power of attorney is a special document independently devoted for the purpose. In other words, it is pertinent to determine whether a principal is free to authorize another so long as such delegation is incorporated in any document in which many matters are jumbled. A host of questions crop up in connection with the form of a power of attorney which must be addressed as they are essential for its validity.

Looking into the relevant laws currently in force, one cannot easily find a ready-made answer to the question whether a power of attorney should be a written instrument. Before further scrutinizing the relevant provisions of the domestic law on the subject matter at hand, it is advisable to dwell on approaches adopted in other jurisdictions in this regard.

French law stresses that a power of attorney can be given either by a public instrument, or by a writing under private signature, even by letter or verbally. Under German law, it is effected by declaration to the person or persons to be empowered or to the third party toward whom the representation is to take place. The declaration need not be in the form which is required for the transaction to which the power refers. Spanish law provides that it must be executed in a public document in specific situations. In England, an agent whose duty is to execute a deed, such as a conveyance of land or a deed of partnership must likewise derive his power from a deed. Similarly, in the United States, agents need no formal requirements except when the law requires the power to be executed with formality or where the power is to execute a sealed instrument. ${ }^{18}$ By and large, it can, therefore, be observed that laws do not totally rule out the possibility of employing forms other than written one for appointment of an agent except in specific situations.

As stated above, Ethiopian law does not provide an easy answer to the query. The form of a power of attorney is a matter recent legislation tries to address, in addition to what is provided for in the Civil Code. In fact, the law does not seem to make form a mandatory requirement for delegation of

${ }^{18}$ Goldblatt, supra note 12 , at 241-244. 
authority; it rather demands that it follow the form the law sets for the main contract. But it must be clear from the outset that a distinction is made between the contract of agency and the ensuing power of attorney. In the Civil Code, the form the law refers to is that of the delegation of authority rather than the contract per se. ${ }^{19}$ A principal may conclude a contract with the agent which governs the internal relationship between them and may, in addition, be required to sign a power of attorney for the purpose of the external relationship.

The contract between an agent and a principal is not subject to a requirement of form. At times, the contract of agency is not even negotiated, if at all it will ever be, by the time a power of attorney is signed. Ordinarily, the parties should agree on the terms of the agency before a power of attorney is executed. In such a case, they are aware of their respective obligations and the delegation is accepted by the agent. But, when a power of attorney precedes a contract of agency or consent of the agent, the former cannot give rise to a contractual relationship between the principal and the agent. The law provides that the agent may accept his appointment either expressly or impliedly ${ }^{20}$ and then the contract will be created. It can be inferred from this that one cannot be said to have accepted his appointment impliedly unless he renders the service professionally or he, otherwise, starts to act based on the delegation given when he fails to reject it outright. Thus, the rules governing form and the requirement set in the law pertain to form of a power of attorney instead of form of the contract of agency.

Another issue worth exploring is whether agency can exist without a power of attorney evidenced by a document. Obviously, one answers this question positively relying on the provisions of the Civil Code. It has already been stressed that one of the sources of agency is a contract concluded between the principal and the agent. As indicated above, the law makes distinction between the contract and the document evidencing authority or the manner such delegation is communicated to third parties. ${ }^{21}$ It is evident that the two are independent. But when it comes to representation, it may be a matter of

${ }^{19}$ See Civil Code, supra note 4, Arts 2180 \& 2200(2).

${ }^{20}$ See $i d$. Art 2201(1). The law makes distinction between professional services and others. Accordingly, if the appointment relates to functions which the agent carries out in an official capacity or professionally, or where he holds himself out publicly for such functions, then it becomes effective unless it is immediately rejected. (2201(2)).

${ }^{21}$ German law makes a clear distinction. A power of representation created by the principal is called 'Vollmacht,' which is merely the power of an agent to change rights and duties of principal; it does not refer to the contractual relationship of principal and agent. See Goldblatt, supra note 12, at 240 
choice left to the principal or a mandatory formal requirement imposed by the law. Article 2184 of the Civil Code states the agent's obligation to return the document evidencing authority when the authority comes to an end. This obligation is, however, contingent upon the existence of such a document since the law states that it can be enforced if such a document exists denoting that it is not an essential component of agency. ${ }^{22}$

The agent may inform third parties as to the authority delegated as can be gathered from article 2181(2) of the Civil Code. Even though the French version of this provision uses the word represente (i.e., the person represented), the Amharic version which (in conformity with the English

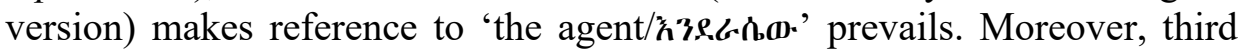
parties may require the agent to produce justification of his authority, and they may require him to produce copy of the document where his authority is evidenced by a document. ${ }^{23}$ It appears, therefore, that delegation can be oral except where it is required by the law. In situations where there is no such requirement, the principal may opt to delegate orally or by a written document. However, article 9 of Proc. No. $922 / 2015^{24}$ states that a power of attorney not only should be in writing but also it has to be authenticated and registered to produce legal effect. The question that naturally follows is whether this is meant to amend the Civil Code or to specifically regulate the situations whereby delegation is effected through a document where the law so requires or if the parties choose to do so.

By and large, Ethiopian law does not rule out authorization without a registered or authenticated power of attorney. In fact, this calls for distinguishing agency based on its source. Agency may arise from a judgment which appoints a person to act on behalf of another. Obviously, the law has no intention of imposing authentication requisite on such document. By the same token, in cases where the law authorizes one to act on behalf of another, there is no requirement for an authenticated document. For instance, the Commercial Code of Ethiopia provides that "an employee in charge of sale in a store shall be deemed to have a power of attorney." 25 Thus, one is not required to demand a salesperson whom he finds in a shop to produce a power

${ }^{22}$ Note the phrase "... if any, ..." in Article 2184 of the Civil Code, supra note 4.

${ }^{23}$ Id. Art. 2186.

${ }^{24}$ The previous proclamation that is repealed, i.e., Proclamation No. 334/2003, has also a similar provision under Article 5.

25 The Commercial Code of Ethiopia Proclamation No. 166 of 1960 (herein after the Commercial Code), Art. 32. The same provision is incorporated under Article 31 of the Commercial Code of the Federal Democratic Republic of Ethiopia Proclamation No. $1243 / 2021$. 
of attorney to conclude a transaction. This shows that, the requirement of authentication does not apply for delegation caused by operation of the law or through a court order.

Yet, the law recognizes some other forms of authorization. For instance, participation in meetings of shareholders of a company can be by proxy. In this case, the Commercial Code provides for delegation through the template a company draws up by appearing before its head office. ${ }^{26}$ This leads to the query whether such delegation is valid given that it is a document and the law requires that the validity of such documents hinges on registration and authentication.

It may be easier to call for the rules of interpretation so as to solve the contradictions among the laws at hand. It is evident that in addition to the general principle, applicable laws embody exceptions to cater for peculiar situations. For example, Article 52(2)(a)(1) of Food, Medicine and Health Care Administration Council of Ministers Regulation No. 299/2013 ${ }^{27}$ provides that a patient who cannot give his consent for medical service can do so through a person authorized by him in writing. The question here is whether this written authorization is required to be authenticated. If not, how can the medical institution or the medical doctor ascertain that it is actually signed by the patient?

The hierarchy of laws compels us to respect what is stated in the proclamation. But, is it in the nature of medical practice (and the emergency situation it is meant to serve) to require one to produce an authenticated power of attorney when someone is in need of medical assistance. It is to be noted that we don't have the culture to execute a power of attorney in advance for medical care, and we should also note that we are not yet adequately aware of the legal implications.

One may argue that where the law declares that the validity of a power of attorney counts on authentication, delegation is not possible unless it is through an authenticated document. However, this line of argument can be challenged based on practical and legal grounds. Proclamation No. 922/2015 recognizes that authentication of documents provides reliable means of

${ }^{26}$ Commercial Code, Art. 402 provides that the form of proxy is determined by directors. The new Commercial Code empowers the board of directors to determine the content and form of proxy. It has even explicitly made it clear that authentication is not required. See article 377 of the Commercial Code of the Federal Democratic Republic of Ethiopia Proclamation No. 1243/2021.

${ }^{27}$ Federal Negarit Gazette, $20^{\text {th }}$ Year No. 11, 24 ${ }^{\text {th }}$ January, 2014. 
evidence $^{28}$ and basically it lays down rules for the authentication of documents. It is not a piece of legislation one resorts to in order to ascertain whether a particular juridical act should fulfill a certain requirement.

Moreover, article 9 of the Proclamation lists documents which must be authenticated rather than determining the form of contract of the underlying transaction or the form of the transaction. The law makes specific mention of "document of power of attorney or revocation" ${ }^{29}$ without prohibiting other forms of appointment. It is, therefore, logical to assert that delegation through a document is not valid unless the document evidencing such appointment is authenticated and registered. Obviously, this cannot bar delegation without a document. Earlier, delegation was effected by a letter written by, for instance, public or private institutions which is no more valid unless it is authenticated. However, so long as there is no special form prescribed for the transaction under the law, the parties may opt to choose any of the forms workable for them such as digital or oral.

In real life, plenty of the transactions are concluded through delegation. Imagine an individual depositing or withdrawing money from a bank handing over or receiving payment from an employee of the bank at the counter. No one requires the employee a written authenticated power of attorney before concluding the transaction. Similarly, when someone buys a thing from a shop, he does not verify whether the seller is owner of the business outlet or whether he is authorized to enter into such transactions.

If we stretch the rule governing authentication of a power of attorney, then the validity of all these and other similar day-to-day transactions conducted would be questioned. In this regard, Article 32 of the Commercial Code (and also Article 31 of the new Commercial Code, i.e. FDRE Commercial Code Proclamation No. 1243/2021), for example, reads "[t]he employee in charge of sales in a store shall be deemed to have a power of agency for the purpose of selling or receiving goods which come within the normal business activities of stores of such nature."

With a view to ensuring smooth progress of business, it is necessary to give recognition to such delegation. We can extend this to other areas of human interaction where the parties opt oral or other form of delegation so much so that persons have the latitude to choose the best form of delegation which suits the circumstances or the nature of relationship or transaction within, of course,

\footnotetext{
${ }^{28}$ See Preamble of Proclamation No. 922/2015, supra note 8.

${ }^{29} I d$., Article 2(1).
} 
the bounds of the law, i.e., unless the law imposes form with regard to the main contract.

It is also essential here to dwell on the status of delegation through technology having electrical, digital, magnetic, wireless, optical, electromagnetic, or similar capabilities. ${ }^{30}$ This requires recognition to such recording and putting in place the proper identification and authentication of data message. ${ }^{31}$ Assuming that we have such a document generated electronically through which someone is delegated, will it be acceptable under Ethiopian law?

The existing law presupposes that authentication relates to written documents and thus electronic documents are not anticipated. The online service provided by DARA is limited to completing the template which generates case number to be submitted to a branch office. It does not avoid physical presence of the delegator and affixing of signature on the document. Encryption and e-signature guarantee the authenticity of the exchange between the parties and because of technological reliability or consent of the parties, the medium may enable them to have a reliable electronic document through which delegation can be effected. If it is the reliability of documents that the law tries to ensure, it can be achieved through encryption or esignature.

Proclamation No. $1072 / 2018^{32}$ gives recognition to electronic documents and it declares that no electronic message shall be denied legal effect, validity or admissibility in any legal proceeding, solely on the ground that it is in electronic form. Where a law requires written form, "such requirement shall be deemed to have been satisfied if such information is rendered or made available in an electronic form and accessible so as to be usable for subsequent reference." ${ }^{33}$ In case of a power granted electronically, it remains to be seen whether the authentication and registration requirement bars its use even if it passes the written form test. Yet, in line with the foregoing argument, it should be up to the parties to choose the form unless the law specifically imposes

30 Article 2(1) of Proclamation No. 922/2015 deals with written matter which is incorporated in a document calling for the inquiry whether other forms are included.

${ }^{31}$ Article 2(9) of Proclamation No. 808/2013 defines cryptography as "a science of coding data so that they cannot be read or altered by any person or any machine other than the intended recipient or a science of authentication and non-repudiation in the electronic transaction." Information Network Security Agency Reestablishment Proclamation No. 808/2013, Federal Negarit Gazette 20th Year No.6Addis Ababa, 2nd January, 2014.

${ }^{32}$ Electronic Signature Proclamation No. 1072/1918, Federal Negarit Gazette $24^{\text {th }}$ Year No. 25, February 2018.

${ }^{33} I d$. Article 5. 
special form, and electronic form should be accepted as a valid form of delegating another person so long as authenticity of the communication is ensured. The requirement of written form and signature can be met even if the document is in electronic form ${ }^{34}$ although it remains to be seen whether this can be extended to authentication requirement.

\section{Authentication}

The role of a notary is significantly different in civil and common law jurisdictions. ${ }^{35}$ The distinctions in the two traditions spring from the responsibility and qualification of the person who undertakes the authentication. A civil law notary is defined as "a legal professional specifically designated to attest the acts and contracts that persons celebrate or perform, to draft the documents which formalize the latter, and to give legal advice to those who require the services of his office." ${ }^{36}$ In the office, attestation and legal service which includes drafting the instrument and ensuring compliance with the law and explaining it to the parties are combined. The civil law notary, in addition to verifying signature on a document, "declares in a written statement that it sets forth transactional facts from which the legal instruments derives and an opinion that the legal instrument satisfies applicable legal requirements and is legally binding." 37

Unlike their civil or Latin counterparts, common law notaries do not certify the contents or veracity of the acts, transactions, or contracts they authenticate. ${ }^{38}$ Accordingly, authentication of a power of attorney is a notarial act in which an individual who appears in person before the Notary Public and presents a document is identified by the Notary Public through satisfactory

\footnotetext{
${ }^{34} I d$., Article 6.

${ }^{35}$ Dante Figueroa (2009), The Evolving Role of the Latin American Notary Public, ILSP Law Journal, Washington College of Law, p. 159.

${ }^{36}$ The definition is provided by the International Union of the Latin Notariat; See Nicholas G. Karamela, 'Civil Law Notary: An Office Whose Time Has Come', Washington Lawyer, March 2005; Available at:

http://www.dcbar.org/barresources/publications/washingtonlawyer/articles/march2005notary.cfm, visited on 8/9/2017;

${ }^{37}$ Ibid. See also Reinhold Geilmer, The circulation of notarial acts and their effect in law, X XIII. International Congress of Latin Notaries Report of the German Delegation, p. 8

${ }^{38}$ Figueroa, supra note 35 , at 159.
} 
evidence of identity and signs the document in the presence of the Notary Public. ${ }^{39}$ Simply, it is an act of verification of a signature on a document.

The disparity in the service given by a notary in the two legal traditions reflects on the persons to be authorized to do the job. In civil law countries, it necessarily required that a notary need to be qualified in law as his role is extended to drafting the documents or advising on its contents and making the necessary modification which is inconceivable without such qualification. On the other hand, in common law countries, one may become a notary public without legal training, or a degree of law, or legal training, whereas in some countries one must have a degree in law or a specific practical training in order to obtain a government license and appointment to assume the responsibility. ${ }^{40}$ It follows, therefore, that in the civil law notary system, notaries should be professional lawyers who are capable of drafting the document they would authenticate, rendering legal advice on the transaction. They may accept or reject or amend a proposal submitted to them since their blessing is not only confirmation of the legality of the document but also the accuracy of its contents. ${ }^{41}$

Ethiopian law defines authentication as signing or affixing "a seal by witnessing the signing of a new document by the person who has prepared such document or the person it concerns and after ascertaining that this formality is fulfilled;" or may also involve signing or affixing "a seal on an already signed document by ascertaining its authenticity through an affidavit or specimen signature and/or seal." 42 Authentication is thus essentially witnessing the signing of a document. A notary has no participation in deciding contents of the document to be signed and it is drawn up by a person other than a notary making it clear that the latter has no part in drawing up the

39 William Francis Galvin, Apostilles and Certificates of Appointment, available at www.sec.state.ma.us/pre visited on 8/9/2017

${ }^{40}$ Figueroa, supra note 35, at 159.

${ }^{41}$ International Union of Notaries <www.uinl.org/principio-fundamentales $>$ visited on 09/10/2017; Notaries should be professionals because first the civil law tradition privileges written evidence and second the system the most important deed need to be entered so that they can be public and accessible to anybody Who is a Latin notary In civil law jurisdictions, the notary: 1) is a lawyer; 2) is also a "public officer" who performs public functions; 3) is a specialized lawyer who draws "authentic deeds"; 4) is a professional who is compelled to keep the original deeds in legal custody, as a public records office; 5) is a multi-party counselor, with a specific, traditional 'antitrial' role. See, The Latin Notary: the Civil Law "title insurance", http://www.notariato.it/eng/home.aspx, visited on 08/9/2017

${ }^{42}$ Proc. 922/2015, supra note 8, Art. 2(2). 
document. The law proscribes a notary to change or cause to be changed the contents of a document submitted for authentication. ${ }^{43}$ Hence, a notary in Ethiopia neither draws up a power of attorney nor does s/he advise regarding its contents.

A power of attorney is characterized by its unilateralism in the sense that the consent of the person who receives it is not required. It is signed only by the principal and authentication embraces identification and verification of signature of the principal. Of course, a power of attorney involves at least two persons: the principal and agent. Ordinarily, one may think that as it involves two persons, it must be signed by both so that it may produce effect and be binding. However, a power of attorney is not a contract and it is signed only by the principal. In the case of a physical person, a person is entitled to delegate another and thus he has to sign the power of attorney personally. But, it must be examined whether a person has to fulfill requirement of competency for valid execution of a power of attorney.

The notary has to ascertain the right or authority and capacity of the person who signs the document. ${ }^{44}$ Capacity to perform a juridical act may be reduced because of age or metal state of a person. Although age may not be that difficult to establish, the standard of determining mental state could be challenging unless the notary limits itself to the legally recognized grounds to limit capacity. Capacity is presumed and anyone who challenges the capacity of another has to prove that the person is under disability. ${ }^{45}$ Setting an acceptable standard of mental health or the sobriety to make the right decision without infringing the rights of clients is crucial. For instance, persons who have hearing impairment may have their own interpreter if they are authorized by the association of persons with hearing impairment. ${ }^{46}$

The signatory of a power of attorney is entitled to select the person whom he delegates and determines the substance of the delegation. This is purely the discretion of a principal which may be limited by reason of public policy reflected in the mandatory provisions of the law or morality. Save such restrictions, the freedom of the principal in the instances mentioned is complete. In a case, the agent was rejected by the third party and the principal was formally advised that it has to appoint another person as the agent appointed is a "persona non grata". Even if the court has not directly

\footnotetext{
${ }^{43} I d$. Article 13(2).

${ }^{44}$ Id. Article 14.

${ }^{45}$ Civil Code, supra note 4, Article 196.

${ }^{46}$ Federal Documents Registration and Authentication Agency, Operational Manual for Documents Registration and Authentication Service Giving (28/2/10170), p. 29.
} 
addressed this issue whether a person may reject the agent selected by another, it ruled that the act of the third party denying the principal to act through a particular person it designated as an agent was illegal. ${ }^{47}$

The fact that the capacity of an agent is not established at the time of execution of a power of attorney leads to the question whether a third party should deny representation of an agent for a reason that he does not have capacity as required by the law. Is a third party obliged to transact with an agent assuming that he is a minor if he represents a principal who has capacity? To put it in another way, can we say that the lack of prohibition in choosing the agent in the law prevents third parties from questioning the capacity of the agent? Ideally, a transaction concluded by an agent is presumed to have been performed by the principal which makes the capacity of the agent irrelevant. Yet, it should be examined whether incapacity of the agent can be invoked either by the principal or the agent.

Article 2189(2) of the Civil Code denotes that it is only defect in consent of the agent that can be invoked by the principal. Considering the restriction in article 1808 of the Civil Code, the limit is justified and capacity of the agent cannot be a ground for invalidation as the principal is not incapable under the law and the agent is not a contracting party. Incapacity of the agent cannot be a ground for invalidation of the contract concluded by an agent on behalf of the principal. This may bring us to the conclusion that third parties should not consider the incapacity of an agent as it cannot affect the transaction they make with the principal. Yet, this does not render the issue irrelevant when we examine the situation by which the agent might be personally liable.

The law squarely places the responsibility to pay compensation on the agent when a contract entered into by an agent is repudiated. If the agent is a minor, does he have such an obligation or shall we apply the provisions designed to protect minors? If the minor is to be relieved of the liability to pay compensation, who is going to be liable to the third party? The point that should be underscored is that the choice to be made as to who is to be appointed as an agent is not merely to be left to the principal as it may impact third parties. Some jurisdictions introduce requirements with respect to qualification of the designated agent. For instance in Ontario, Canada, as long

${ }^{47}$ Following the denial of access to a delegate of one of its members in its general Assembly, two suits were instituted; by the principal and the agent. See http://capitalethiopia.com/2014/06/16/chamber-president-firesback/\#.W2sQpdIzY2w; see also Fortune, Court Cancels Chamber of Commerce Assembly, https://addisfortune.net/articles/court-cancels-chamber-of-commerceassembly/ 
as the named attorney is of legal age and able and willing to act, he or she can exercise the powers of an attorney. ${ }^{48}$ This evokes the question whether we should require some qualification of the agent in Ethiopia, or whether we need an explicit provision affirming that the principal makes the choice at his own risk.

After identifying the person who should sign the power of attorney and ascertaining capacity or authority to do so, the next step is examination of contents of the document submitted for authentication. Determining the boundary of the power of the notary in ascertaining the legality of the document or looking into contents of the instrument submitted for notarization can be tricky. For instance, if one authorizes another to pay tax on his behalf, should a notary make sure that the would-be principal has the duty to pay tax? Should one prove that he has property to be administered so as to appoint an agent to administer his property? One may not have tax obligation right now but he may expect some income anytime soon or he may acquire property soon.

We have seen above that, a notary in civil law is an attorney who has undergone special training and performs three functions, namely, drafting, authenticating and depositing legal documents while in the common law a notary public basically administers oaths, takes sworn statements, and verifies the identity of a person who executes a legal document. ${ }^{49}$ In Ethiopia, accuracy of facts is not perceived as duty of a notary since s/he can solely ensure the legality of the document such as determining that what is stated in the document is not contrary to the law. In effect, the principal enjoys maximum freedom to determine what should go to the document so long as it is not illegal or immoral.

After such scrutiny, a power of attorney must be endorsed by the principal by affixing of signature and attesting the same. This assures that the power of attorney is signed before the notary. In cases where the principal has authorized another to delegate on his behalf, delegation can be effected by an agent in which case the physical presence of the principal is not mandatory. The document should not be signed in advance except by those who have deposited specimen signatures at the office in which case it will be verified against the specimen kept by the agency. The signing can be done by writing one's name or affixing a symbol or mark.

\footnotetext{
${ }^{48}$ Margaret E. Rintoul (2010), Power of Attorney Jurisdictional Issues, Canadian Bar Association, Canadian Legal Conference, Ontario, August 17, 2010, p. 3.

${ }^{49}$ Karambela, supra note 36, at 1.
} 
An agent does not sign a power of attorney and even it can be executed without his knowledge. He is relieved from appearing in person and the notary has no way of knowing whether the agent is alive, capable, and sane or not. This is mainly a contractual relationship and there cannot be a contract until and unless one of the contracting parties gives his consent. We have seen above that the contract and the document evidencing the delegation are distinct. The mere execution of a power of attorney does not give rise to a contractual relationship between the principal and the person named as an agent. It is not, therefore, necessary to have the consent of the agent for the execution of a power of attorney.

After the principal affixes his signature ${ }^{50}$, the notary affixes a notary seal (rectangular stamp with particulars of the authentication) in which a declaration is made that it was signed before the notary and indicated its serial number and date. Finally, a circular stamp is affixed. Stamp duty shall be paid ${ }^{51}$ in the absence of which it cannot be accepted as evidence. ${ }^{52}$ Like other civil law countries ${ }^{53}$, a power of attorney is signed in many copies but the original is kept by the notary and a certified copy is used. That is why you find in other copies a stamp confirming that stamp duty has been paid on the original.

With the advance in technology and progress in means of communication, the traditional method of authenticity is challenged. It is submitted that with the emergence of electronic commerce and digital documents and signatures, the intervention of a notary is arguably an obstacle to the promotion of business. ${ }^{54}$ As we have seen above, legal systems can hardly accommodate electronic documents in the traditional paper based laws. Therefore, legislatures have passed targeted amendments to laws to allow the expansion of electronic commerce. ${ }^{55}$ This could be a quest to be addressed in Ethiopia with the rise in demand for the use of electronic documents or transactions.

${ }^{50}$ There are legal systems which recognize signature by another person under the direction of the principal. If for some reason the principal cannot sign his name, he may seek the assistance of another person who accompanies him to a notary and signs under his direction. For instance, Section 5 of the Revised Uniform Law on Notarial Acts, National Conference of Commissioners on Uniform State Laws, 2009.

${ }^{51}$ Stamp Duty Proclamation No. 110/1998, Art. 3(11), Federal Negarit Gazette, $4^{\text {th }}$ year No. 36, 1998. The annexed schedule indicates the Birr 35 stamp duty must be paid.

${ }^{52}$ Id., Stamp Duty Proc. No. 110/1998, Art. 10(1); Proc. No. 922/2015, supra note 8, Art. 34.

${ }^{53}$ Eder, supra note 2, at 6.

${ }^{54}$ Figueroa, supra note 35, at 159.

${ }^{55}$ Id. At 160 


\section{Legalization and Apostil}

Based on the principle that the origin of the document lies in the document itself (acta probant sese ipsa) ${ }^{56}$, a document executed in Ethiopia need not be verified. However, when it is executed abroad, the recipient requires verification since "the recipient may not be familiar with the identity or official capacity of the person signing the document, or the identity of the authority whose seal/stamp it bears. ${ }^{, 57}$ A power of attorney may originate from a jurisdiction to be used in the host state. It is maintained that the power of attorney is one of the most frequently used instruments in international intercourse, ranking next to the bill of exchange and the bill of lading. ${ }^{58}$

This presupposes a power of attorney crossing borders to be employed in another jurisdiction. Since the host state cannot know the identity and official capacity of the person who authenticated the document, there must be a mechanism to extend the utilization of the document beyond the local limits of the country in which it was executed. This calls for the need to ascertain whether it originated from the country where it was executed. In such a case, the document must fulfill not only the requirements in the country of origin but also the conditions for its validity in the country of destination.

In the context of a federal state structure, a power of attorney may encounter a problem if it is to be submitted in a state other than it was executed. In the United States, States give each other full faith and credit as per the US constitution ${ }^{59}$ and they recognize public acts of, records and proceedings of every other state. Likewise, cognizant of the potential problem that may arise, Article 24 of the Proclamation No. 922/2015 states that a document authenticated by a federal institution is acceptable by the states and a document authenticated by a state institution is acceptable by the federal government and the other states.

With respect to international acceptance of an authenticated document, countries can generally have different requirements depending on membership

${ }^{56}$ Apostille Handbook, A Handbook on the Practical Operation of the Apostille

Convention available at https://assets.hoch.net/upload/apostille_hbe.pdf p. 3

57 Ibid.

${ }^{58}$ Eder, supra note 2, at 1.

${ }^{59}$ Article IV, Section 1 of the United Sates Constitution, available at https://constitutioncenter.org/media/files/constitution.pdf, The section reads: 'Full Faith and Credit shall be given in each State to the public Acts, Records, and judicial Proceedings of every other State. And the Congress may by general Laws prescribe the Manner in which such Acts, Records and Proceedings shall be proved, and the Effect thereof.', 
or non-membership to the Hague Convention which may lead to legalization or apostilization. Although both entail similar effects, apostilization is the result of a simplified one-step process established by the Convention as opposed to the multiple-steps process of legalization. ${ }^{60}$ Hence, it is necessary to examine the authentication process when an authenticated document comes into or goes out of Ethiopia.

The process known as legalization developed because states have to require certification of the origin of a foreign document by an official who is familiar with the document. 61 It involves "the procedures whereby the signature/seal/stamp on a public document is certified as authentic by a series of public officials along a chain to a point where the ultimate authentication is readily recognized by an official of the State of destination and can be given legal effect there."62

If, however, a country is a signatory of the Hague Convention ${ }^{63}$, the verification process becomes easier: documents are signed and/or executed in the presence of a Notary Public, then the Notary Public will attach his Certificate of Authentication to the documents which must bear his signature, stamp and seal. They are forwarded to the High Court in the area in which the Notary Public practices. The Court will then attach an Apostil Certificate authenticating the Notary Public's signature. ${ }^{64}$ Apostil authenticates only the origin of the document and thus has the following limitations: it does not certify contents of the underlying documents or the fulfillment of the requirements for the proper execution of the document under domestic law. ${ }^{65}$

Ethiopia is not a party to the Hague Convention ${ }^{66}$ and thus apostil certification is not acceptable if the document originates from outside Ethiopia or one cannot obtain such certification in Ethiopia. Legalization is the only means of verification in Ethiopia for documents coming from abroad and it involves authentication by the relevant organ and the Ministry of Foreign Affairs if it is required to be sent to a country which requires authentication. ${ }^{67}$

\footnotetext{
${ }^{60}$ Apostille Handbook, supra note 56, at 62.

${ }^{61}$ Ibid.

${ }^{62} \mathrm{Id}$. at 3 .

${ }^{63}$ The Hague Convention of 5 October 1961 which aims at abolishing the requirement of Legalization for Foreign Public Documents entered into force on 24-I-1965; See, ttps://www.hcch.net/en/instruments/conventions/

${ }^{64} \mathrm{http}: / / \mathrm{www}$. straussdaly.co.za/wp-content/uploads/2015/04/Authentication-ofdocuments-executed-inside-and-outside-South-Africa.pdf, visited on 16/09/2106

${ }^{65}$ Apostille Handbook, supra note 56, at 10.

${ }^{66}$ See https://www.hcch.net/en/instruments/conventions/status-table/?cid=41

${ }^{67}$ Article 6(2)(b) of proc. No. 922/2015
} 
If a document is to be sent to Ethiopia, Ethiopian Embassies and Consular Offices ${ }^{68}$ or embassies and consular offices of foreign countries in Ethiopia shall verify it; and it shall then be submitted to the Ministry of Foreign Affairs for authentication. ${ }^{69}$

Generally, authentication originating from a foreign country should comply with the legalization process in the country of origin and thus be processed by the embassy or consulate of the country of origin or destination before it is submitted to the Ministry of Foreign Affairs. The Ministry is an intermediary organ because "Embassies and Consulates do not maintain samples of the signatures /seals / stamps of every authority or public official in the State of origin." $" 70$

A country may choose legalization or apostilization even though the tendency is towards reducing the lengthy process of authentication. Apostilization is introduced to abolish legalization with a view to reducing the lengthy process of attesting the origin of a document. Traditionally, the lengthy process of legalization was the means of authenticating documents to be used across borders. The Convention was needed to replace the cumbersome and often costly formalities of a full legalization process. ${ }^{71}$ Any document apostilled in a member state of the Convention is acceptable in all member states (which are more than 105 countries) without additional formalities.

\section{Contents and Construction}

The template of a typical power of attorney can be divided into three parts: the caption, the body and signatures. ${ }^{72}$ It should be stressed that the template ${ }^{73}$

${ }^{68}$ Foreign Service Proclamation No. 790/2013, article 45 provides that a consular office has the power and duty to provide documents registration and authentication service.

${ }^{69}$ Proc. No. 922/2015, supra note 8, Article 6(1) and (2)(a).

${ }^{70}$ Apostille Handbook, supra note 56, at 3.

${ }^{71}$ Outline Hague Apostille Convention, Hague Conference on Private International Law, available at www.hcch.net.

${ }^{72}$ The pattern represents almost all powers of attorney executed before the Agency; and subsequent discussion is based on the practice which anyone encounters appearing before the Agency. The personal experience the author over the years (as a client of the Agency) and information gathered from informal discussion with other lawyers corroborates what is stated herein.

${ }^{73}$ Though it is not legally sanctioned, it is hard to find an exception to the traditional template except when the power of attorney originates from abroad. On the top right side of a power of attorney, the date of the document is indicated. As required by the notaries, it must correspond with the date of the execution. Next, on the left side, the 
in general and the caption ${ }^{74}$ in particular raise many issues ${ }^{75}$ which adversely affect the exercise of rights by citizens. This section focuses on the substance in the body of a power of attorney which contains the ingredients of the delegation.

The principal's decision to delegate hinges on a number of factors ranging from the need of the principal to his relationship with the agent which further affects the scope of power to be delegated. Power of attorney is an instrument of delegation of authority and the person who delegates another person to represent him before third parties determines its contents. It proves the substance of the delegation (to the principal, the agent and a third party). The trustworthiness of an agent ${ }^{76}$ and the care the principal exercises in selecting the agent reduces the risk of misuse or abuse of the authority delegated.

name and address of the authenticating organ is inserted. A power of attorney is usually addressed to this organ and at the Federal level, a power of attorney is addressed to the Agency. One may not help but wonder why one addresses to a notary, a document through which one handles his private matters as if it were a plea.

${ }^{74}$ Though, understandably, the names and addresses specified in a power of attorney help to individualize the parties, it is common to observe that their nationality is indicated in a power of attorney as a prerequisite for executing the instrument. It is one of the requirements without which execution of the document is not possible following the practice in the Agency. All facts and information necessary for validity of a power of attorney should be stated. However, one may wonder why nationality becomes essential if it does not affect validity or does not help in identifying the parties. The law recognizes it as a ground entailing special disability (see Civil Code, Article 194); which should only be checked just like age or marital status (as the need arises) instead of including it as a requirement in a power of attorney. In some transactions such as purchase of a real estate, the nationality of the buyer may be essential even though it is to be established at the moment of conclusion of the contract rather than making it a prerequisite for execution of a power of attorney. It is evident that the law does not provide this requirement; nor does it authorize a notary to do so. Please look at Article 10 of Proc. No. 922/2015 which does not allow notary to ascertain nationality of persons who are about to sign).

${ }^{75} \mathrm{I}$ know of a sale agreement in which the name of the agent was mentioned as the buyer by the instruction of the notary and the contract was rejected when the principal applied for registration of the property in its name. This has also become an issue in a case decided by the Cassation Division of the Federal Supreme Court. See, Liqe Seyouman Assefa Bashawured v Sahlite Meheret and Kiristos Semra Parish Administration, Federal Supreme Court Cassation Division Decisions, Vol. 5, File No. 23861, Yekatit 26, 2001 E.C.

${ }^{76}$ Regina M. Spielberg, The Powerful Power of Attorney, http://www.spsk.com/tasks/sites/spsk2/assets/Image/powerful.pdf; visited on 6/9/2016 
However, careful consideration of the contents of a power of attorney is another safeguard for the principal which must be decided based on consultation with a legal counsel. Likewise, care should be taken to ensure that the authority granted is sufficient for the purpose, in particular to carry out activities which require special authority. More often than not, principals sign a template provided by clerks in the vicinity of a branch office of the Agency which may be a source of disagreement or dissatisfaction in the course of the exercise of delegated power by the agent. Lately, customers are supposed to sign on the template prepared by the Agency if they get the service through online registration with little or no room for modification of the template.

Choice of the language (the principal uses) to confer authority is relevant in a diversified polity like ours and with a significant number of expatriates living in the country. In particular, one has to be fully aware of the rights one allows others to exercise on his behalf and this calls for a choice of the language to enable the principal grasp the overt and covert message of the language employed to effect the delegation. The notary should also know the contents of the documents it authenticates given that it has to verify its legality. ${ }^{77}$ It is fair to state that a foreigner should not be compelled to use one of the local languages which he or she does not understand.

Yet, it can be cumbersome on the offices to demand that they have notaries capable of understanding all foreign languages. In this regard, the manual issued by the Agency provides that a foreigner should be accompanied by an interpreter who brings a letter certifying his proficiency from the Embassy of country of origin of the concerned foreigner. The interpreter has the duty to confirm that he interpreted correctly and certify the same by signing on the back of the power of attorney. ${ }^{78}$ Citizens may have the same problem when they speak a language other than the working language of the area where the power of attorney is to be executed. The approach in other jurisdiction is not identical as some states limit public documents to those that are expressed in the official language while others do not designate an official language. ${ }^{79}$

${ }^{77}$ Proc. 922/2015, supra note 8, Art. 8(5).

${ }^{78}$ Operational Manual, supra note 46, at 29.

${ }^{79}$ Apostille Handbook, supra note 56, at 42; In Germany, deeds are drafted in principle, in German. However, the notary can also draw up the deed in another language in accordance with section 5, paragraph 2 of the Notarization Act, if he has sufficient knowledge of it. See Dr. Reinhold Geilmer, The circulation of notarial acts and their effect in law, X XIII. International Congress of Latin Notaries Report of the German Delegation, p. 12 
The body of a power of attorney contains the substance of the delegation prepared by the principal himself or drawn up by another person on his behalf. With regard to the practice, it is worth inquiring into the degree of freedom enjoyed by the principal in determining the contents of a power of attorney. It has been commonplace to witness notaries dictating the contents or wordings of a power of attorney which includes giving instructions to accomplished lawyers to modify or change the draft they submit. The approach in other jurisdictions is marked by flexibility which enables individuals to adopt statutory form or come up with a tailor made power of attorney. ${ }^{80}$

Ethiopian law does not introduce statutory forms or models, instead one of the powers given to the Agency is to draw up model documents. ${ }^{81}$ Even though, some templates have been provided by the Agency, it can be perceived that it is not used much as the approach is more on directing the terms of each power of attorney submitted for attestation rather than promoting or encouraging clients to use the model as it is or with some adaptation.

By virtue of the law, individuals are free to determine the extent and substance of the power they wish to delegate to their agent subject to specific legal limitation. This limitation may relate to the requirements to be fulfilled to confer a special authority on the agent. Such is the case when the power to be delegated relates to an immovable property and the law requires that the principal may be required to produce evidence in order to prove his title over the property. However, in practice, clients frequently receive instructions from the officers of the Agency either to add to or to omit something from the draft submitted. ${ }^{82}$ With a view to clarify the confusion surrounding the

${ }^{80}$ Revised Uniform Law on Notarial Acts, National Conference of Commissioners on Uniform State Laws, 2009, Article 2

${ }^{81}$ Regulation No. 379/2016, Federal Authentication and Registration of Documents Agency Establishment Council of Ministers Regulation, Federal Negarit Gazette, Year 22, No. 50, March 24, 2016, Article 6(5)

${ }^{82}$ It can be observed that the practice in the Agency is dictation of the terms and words to be used or articles to be cited. Those who render the secretarial service in the surrounding area of branches of the Agency offer to advise whoever comes to a branch office and recommend a draft which will be accepted by the officers of the Agency. They know what the notaries would approve and almost everybody prefers to get their services instead of being rejected. Sometimes, even lawyers advise their clients to get the service lest they would be embarrassed before their clients and ironically sometimes they themselves procure it. Advocates voice their objection against such practice frequently. See for instance Gezu Ayele Mengistu (

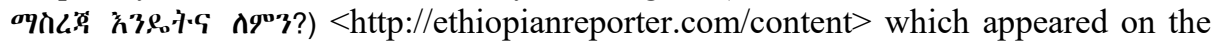
weekly Reporter Newspaper on 08 May, 2016; See also, Operational Manual for 
determination of the contents of a power of attorney, it is advisable to explore limits of the power exercised by notary or of the freedom anyone who desires to delegate another enjoys.

The latest law seems to have recognized the adverse effect of the hitherto practice and it places restriction on notaries regarding the power they can exercise in determining the contents of a power of attorney which is confined to ascertaining that the contents of a document are not illegal or immoral. ${ }^{83}$ The law has made it clear that they shall not have power to change or cause to be changed the contents of a document submitted for authentication. ${ }^{84}$ Notaries may refuse to authenticate a power of attorney which is illegal because of its contravention of a provision of the law or because it has an immoral content. The first is decided based on a clear provision of the law while the determination of the latter is not always easy in the absence of an agreed set of standards determining behavior of members of the community which, perhaps, is exacerbated by the diversity of cultures in Ethiopia.

As to what the principal can delegate is clear: it must be a right which he can exercise or a duty he has to discharge. It must be a subject matter which can rightfully be done by the principal. The act to be done by the agent must be legal and morally acceptable. ${ }^{85}$ Some rights and obligations are strictly personal and they cannot be delegated. Conclusion of marriage and will ${ }^{86}$ are typical examples. Further, a contracting party's obligation under personal contracts cannot be delegated. The delegation of authority pertains to rights and obligations which one can exercise and amenable to delegation.

The other common practice which has become a norm is incorporating a provision of the Civil Code or the Civil Procedure Code which more often than not is required for completing the process at a notary office. The most common provision which one finds in the majority of powers of attorney is article 2199. Likewise, depending on the type of power of attorney classified

Documents Authentication Registration Service Giving, Federal Documents Registration Agency (2017) p. 6 available on http://www.dara.gov.et

${ }^{83}$ Proc. No. 922/2015, supra note 8, Art. 13(1)

${ }^{84}$ Id. Art. 13(2)

${ }^{85}$ Provisions governing contracts in general lay down that the object of a contract must be licit. Similarly a power of attorney, an instrument by which agency is achieved, must be a corollary of the contract between the parties.

86 See Article 12 of the Revised Family Code (Federal Negarit Gazette $6^{\text {th }}$ year Extraordinary Issue No. 1, 2000) personal presence of each spouse is necessary and the law recognizes one exception where representation is permitted. Thus, the Ministry of Justice (Office of the Attorney General) may dispense with this requirement in the event of serious cause. See also Civil Code, Art. 857/2/ 
under the manual issued by the Agency, articles 2204 or 2205 of the Civil Code and articles 58 or 63 of the Civil Procedure Code ought to be cited so that one can easily execute a power of attorney. Yet, it is a requirement which must be complied with for one to get a power of attorney executed. ${ }^{87}$

Obviously, this practice, if it is not a requirement, is not the wish or desire of all principals. But somehow it is so entrenched that it has become a pattern of behavior enforced or promoted consciously or unconsciously. Though it may be regarded as inconsequential, it became a subject matter of dispute in a case which was finally settled by the Cassation Division of the Federal Supreme Court in which a principal was prevented from exercising special authority expressly granted merely because Article 2205 (the provision describing special authority) was not cited in the power of attorney. The court concluded that it is unacceptable to deny validity of a power of attorney simply because the relevant provisions of the law are not mentioned while its contents are clear. ${ }^{88}$

For that matter, the articles commonly cited do not add substance or value to the contents of a power of attorney. Article 2199 does nothing more than defining agency. A power of attorney, as defined above, is a document through which power is delegated it does not need to incorporate a provision defining agency. Similarly, referring to article 58 of the Civil Procedure Code is not mandatory, as the provision enumerates the agents of parties to a litigation by whom appearances, applications and acts may be made or done before courts. A principal should state the authority he wishes to delegate and if judicial representation is one, it must be specifically denoted. There is no reason, legal or practical, to demand that a specific provision of the law be mentioned which, perhaps, can merely be consulted by the notary to determine whether the law prohibits such delegation.

The scope of power granted to an agent hinges on the expressed pronouncements and whatever may be implied from the expressed terms of the delegation. As discussed in the subsequent section, the law classifies authority as general or special. Depending on its contents, a power of attorney may be special, general or both. Contrary to the popular belief, a general authority limits the delegation to acts of management while special authority involves the authority to what has been specified. The law is fairly clear in marking the boundary between the types of authority. Nevertheless, it requires

\footnotetext{
${ }^{87}$ See Gezu Ayele, supra note 82.

${ }^{88}$ Nigisti Emnet $v$ Tewodros Kifle, Federal Supreme Court Cassation Decisions, Vol. 13, File No. 72337, Yekatit 26, 2004 E.C
} 
construction of a power of attorney when a specific act is to be undertaken by the agent.

For instance, the question whether the authority conferred on an agent to enter into a contract can encompass authority to, for instance, sale or buy a thing can be raised. The Cassation Division of the Federal Supreme Court rightly maintained that such terms relate to contracts to be concluded in the course of carrying out acts of management and cannot be construed to empower an agent to conclude a contract which needs special authority. ${ }^{89}$ Similarly, it may be inquired whether an agent who is authorized to sell an immovable is also authorized to mortgage it. The Cassation Division of the Federal Supreme Court answered the query in the positive in the judgment it rendered in File No. $17320^{90}$ which is a binding decision to be applied to successive cases before lower courts that involve similar issues.

In most civil law countries, a broad power of attorney should be interpreted very strictly while in minority of civil law countries no statutory rule is provided to limit the meaning of general terms. ${ }^{91}$ Ethiopian law subscribes to the former approach and provides that terms in a power of attorney should be interpreted restrictively. ${ }^{92}$ In Commercial Bank of Ethiopia versus Shawel Gebre $^{93}$, the Federal Supreme Court Cassation Division held that a power conferred on an agent to sell an immovable encompasses the power to charge it with mortgage. It is, however, to be noted that one who delegates another to mortgage an immovable cannot be considered as having also intended to authorize its sale. If at all the court finds it doubtful, the law demands that the court interpret it to the effect that the power is restricted rather than broadened. If it is uncertain that sale and mortgage are not the same, the right thing to do is to limit the authority only to sale rather than extend it to mortgage, which are entirely distinct transactions.

In this particular case the agent used the power of attorney granted to secure the loan he got from the bank on his own behalf. Though it has not conspicuously surfaced, the issue whether the agent acted in the interest of the principal was a pertinent question which should have been addressed. This triggers the query whether the acts listed in a power of attorney should be

\footnotetext{
${ }^{89}$ Sishah Kifle et al v Atsde Dube et al, Federal Supreme Court, Vol 13, File No. 50985, Hidar 05, 2004 E.C.

${ }^{90}$ Commercial Bank of Ethiopia $v$ Shawel Gebre et al, Federal Supreme Court Cassation Decisions, Vol. 5, Megabit, 18, 2000 E.C.

${ }^{91}$ Goldblatt, supra note 12, at 246.

${ }^{92}$ Civil Code, supra note 4, Art. 2181(3).

${ }^{93}$ CBE v Shawel Gebre et al, supra note 90.
} 
construed to the effect that they are to be undertaken in the interest and for the benefit of the principal. Apparently, it is the law that provides so, and the exercise of the right by virtue of a power of attorney is exclusively in the interest of the principal. ${ }^{94}$ If a power of attorney incorporates terms which enable the agent to charge property of the debtor with mortgage, it is obvious that it should be for the exclusive interest and benefit of the principal.

One may wonder if a power of attorney can be granted to an agent so that only the agent benefits from it. In practice, it is commonplace that in transactions which cannot be completed immediately (either because of legal ban or practical considerations), parties employ a power of attorney to transfer the power to discharge the obligation under the contract they conclude directly to the other contracting party or a third person designated by the latter. For instance, sale of a house or a vehicle may be concluded without complying with the formal requirements and it is performed (payment and delivery effected immediately) but signing of the contract before a notary is deferred in which case the buyer requires the seller to sign a power of attorney authorizing someone designated by the buyer to perform acts necessary for the fulfillment of contractual obligations. The intention here is not employing a power of attorney as an instrument of delegation by which the rights of the principal is to be affected. Instead, the performance as per the delegation is for the benefit of the counter party who, for all intents and purposes, has acquired the right. Hence, the power of attorney is executed for the benefit of a third party and the fidelity of the agent is to the third party rather than to the principal.

The question that follows is whether the contractual arrangement of contracting parties could alter the essence of an instrument the law recognizes and thereby ascribe to it some novel features. By definition, a power of attorney is an instrument by which delegation is effected so that the agent affects the rights and obligations of the principal. Individuals should not be allowed to come up with an idea which may change the essence of an instrument, and it should remain what the law deems it to be in spite of the wish of the parties otherwise.

\section{Types of Power of Attorney}

The law classifies powers of attorney into different categories and gives distinct effect to each of them. The approach in classification is not the same in different jurisdictions. Ethiopian law recognizes special and general power

\footnotetext{
${ }^{94}$ Civil Code, supra note 4, Art. 2209 (1)
} 
of attorney. ${ }^{95}$ A power of attorney is special where it incorporates authority to perform acts other than acts of management. If a power of attorney limits the power given to the agent to those acts which are deemed to be acts of management, it is a general power of attorney. In most civil law countries, general powers of attorney apply only to acts of management, not to acts of disposition. ${ }^{96}$ It is important, therefore, to distinguish acts of disposition from acts of management. The classification is not demarcated because a single power of attorney may contain both general and special authority that are conferred simultaneously. Thus, it may be questioned whether the genre refers to type of authority to be granted rather than the type of power of attorney.

The procedure manual of the Agency recognizes five kinds of powers of attorney: General, Special, Management, Family and Attorney-at-law. ${ }^{97}$ The classification seems to target at convenience and facilitate the work flow of the Agency. It is based on the legal effects that they produce or the requirements that must be fulfilled under the law. The manual lists the requirements for each type of power of attorney. The classification appears to follow the classification of the Civil Code and the Civil Procedure Code since they rely on a specific provision of the law. General, Special, Management, Family and Attorney-at-law are based on articles 2203, 2205 and 2204 of the Civil Code and articles 58 and 63 of the Civil Procedure Code.

Articles 2203 and 2204 are described as two types of power of attorney: one general and the other managerial. But the substance of the provisions does not warrant such dichotomy since they deal with the same thing: general authority. Comparing articles 2204 and 2205 which are utilized as a basis for the classification, one understands that there is no clear demarcation as far as the content of a power of attorney is concerned. In other words, a power of attorney may confer general as well as special authority rendering the classification meaningless for the purpose of conferring power using a power of attorney.

Articles 58 and 63 of the Civil Procedure Code are used to identify two types of powers of attorney, i.e., family and advocate's power of attorney. These provisions do not deal with a specific type of power of attorney. They refer to a person who may be allowed to appear before a court on behalf of another. They do not give rise to a type of power of attorney unless it can be

\footnotetext{
${ }^{95}$ In fact, the law seems to refer to the power rather than the instrument which contains the delegation. However, depending on its content, a power of attorney can be special, general or mixed.

96 Goldblatt, supra note 12 , at 245

${ }^{97}$ Operational Manual, supra note 46, at 3
} 
said that attorney-in-fact is distinguished from such type of power of attorney. Of course, it can be said that the classification is a practical way of streamlining service delivery of the Agency without taking into account the legal and theoretical ramification of such classification. However, it has impact on the exercise of rights of citizens who are often required to cite the provision in the power of attorney or who may be made to sign different documents for conferring such power.

Other jurisdictions have other categories of powers of attorney accompanied with the standard legal effect they produce. A power of attorney may be general or limited, durable or non-durable and immediate or springing. A general power of attorney gives broader power while limited power of attorney contains language that authorizes one or a few tasks, often related to a specific event. ${ }^{98} \mathrm{~A}$ power of attorney may be characterized as durable if it is not terminated by the principal's incapacity. ${ }^{99}$ It is distinctive from a regular power of attorney and allows the agent to act on the principal's behalf beyond the incapacity of the principal. ${ }^{100}$ It may further be divided into springing and immediate; the former goes into effect after a specific event occurs while the latter starts immediately after the power of attorney has been executed. ${ }^{101}$

Ethiopian law does not seem to recognize such types of power of attorney save what can be inferred from some provisions of the law. For instance, there seems to be consensus in practice that agency is terminated upon death or incapacity of the principal or the agent. But, the law recognizes an exception to this generalization and gives room for an agreement otherwise. ${ }^{102}$ In other words, parties can set aside the default rule by providing otherwise. This gives the room for durable power of attorney as the law permits the parties to give effect to a power of attorney beyond the grounds which otherwise bring an end to the principal-agent relationship. Some try to interpret the proviso "Unless agreed otherwise...," to refer to the continuation of the exercise of power by heirs of the deceased. ${ }^{103}$ But, the question here is whether

${ }^{98} \mathrm{http}: / / \mathrm{www} \cdot$ brianneilburg.com/pageview.php?pageid=6 and see also http://info.legalzoom.com/difference-between-general-power-attorney-limited-powerattorney-20392.html visited on October, 8, 2016.

99 See Uniform Power of Attorney Act, National Conference of Commissioners on Uniform State Laws, 2008, Section 104.

${ }^{100}$ Law Dictionary: http://thelawdictionary.org/article/what-is-a-durable-power-ofattorney/\#ixzz2qhoRY5Pb

${ }^{101} I d$.

102 See Articles 2230 and 2232 of the Civil Code, supra note 4.

${ }^{103}$ Hawet Hailegizi and Addisu Damtie (2009), Ethiopian Law of Agency Teaching Material, Justice and Legal System Institute, p.146 
representation would continue after incapacity or death of the principal and the heirs should not be bound by the stipulation in the power of attorney, if any.

This needs careful reference to the law, because in some legal systems durable power of attorney may survive all incapacity except death of the principal. ${ }^{104}$ However, such interpretation is not tenable because it results in selective application of an explicit provision of the law thereby modifying its content. Hence, there can be agreement otherwise; and durable power of attorney can be said to be included under Ethiopian law. Similarly, the extension may emanate from the law. Apart from the agreement deviating from the default rule, the law rarely extends the application of a power of attorney beyond the death of the principal. Art. 753(3) of the Commercial Code provides that the agency granted by a power of attorney shall not terminate by reason of the death of the principal or his becoming legally incapable. Thus, an agent may endorse a bill of exchange after the death of the principal which otherwise could have been made impossible upon occurrence of any of the incidents mentioned.

The assertion that a durable power of attorney can be conceived in the existing legal framework in Ethiopia based on the proviso in an article calls for a number of questions. The first is as to when the power of attorney is going to terminate. The second is as to whose interest the agent is going to uphold during the period before the person who is entitled to exercise the rights takes over. The third touches upon the scope of power of the agent during the interim period. In line with the conclusion that a principal may grant durable power to the agent, more questions crop up which the law does not address.

The other classification is based on the time when a power of attorney becomes effective. Almost all powers of attorney in Ethiopia are immediate and it is pertinent to inquire whether a principal can draw up a power of attorney which becomes effective on a certain future date or occurrence of a certain event. Obviously, so long as it is not illegal, a principal is at liberty to determine the contents and the time when it becomes effective. Since it is up to the parties to set the time when a power of attorney produces effect, it can be concluded that this classification is recognized in Ethiopia, as well.

A power of attorney may also be revocable or irrevocable based on the discretion of the principal. Usually, delegation is undertaken for performance

${ }^{104}$ Kimberley Fowler, Misconceptions about a Power of Attorney, https://www.aplaceformom.com, visited on 10/8/2018 
of a specified task and/or for a specified period. It is naturally terminated upon accomplishment of the task or expiry of the period of time set. It is appropriate to raise a query whether the principal can waive his right to revoke the power of attorney contractually or make it subject to the approval of the agent. This may be the case where the agent has interest in the continuation of the agency; and contractually the right to terminate the contract is restricted. Ethiopian law prohibits an agreement by which a principal waives the right to revoke a power of attorney. ${ }^{105}$ Usually, a power of attorney is made irrevocable if the agent has interest in its duration. In the context of Ethiopian law, however, it is through the underlying contract (employment, agency, etc.) that such concerns can be accommodated.

Sometimes, distinction is made between powers of attorney on the basis of their intended purpose. A typical case in point is medical power of attorney in which one appoints another person to make medical decisions on behalf of the former in case one is unable to do so. It empowers the agent to consent or refuse treatment on behalf of the principal, to employ or discharge health care personnel or release of medical information.

Some legal systems recognize power of attorney for personal care which enables the principal to designate someone who will have authority to make personal care decisions on his behalf if he becomes mentally incapable ${ }^{106}$. The rule is that incapacity of a person terminates a power of attorney (under Ethiopian law) and it seems doubtful to have such kind of power of attorney in Ethiopia. However, as has been discussed above, the law allows agreement otherwise and this should be allowed if one requests to appoint an agent for personal care. In fact, it may be argued that the solution to such incapacity is judicial interdiction rather than power of attorney for personal care. However, one does not exclude the other in addition to the fact that judicial decision is the outcome of a relatively prolonged judicial process which does not fill the gap created following the occurrence which entails incapacity that necessitates immediate intervention.

Often, the power conferred on a lawyer through a power of attorney is treated separately. Although, no special rules apply to such a power of attorney, it is treated distinctly because of the nature of the relationship formed between a client and his lawyer. Of course, this relationship is subject to the rules of agency. However, because of the regulations of the profession, some specific conditions are attached owing to the nature of the relationship. An

\footnotetext{
${ }^{105}$ See Civil Code, supra note 4, Arts. 2185(2) and 2226 (2)

${ }^{106}$ Power of Attorney, Ministry of the Attorney General, Ontario, Queen's Printer for Ontario, 2012
} 
advocate is an officer of the court in which he practices and, in some sense an officer of the state. ${ }^{107}$ Some scholars distinguish the power granted in relation to court proceedings and other purposes ${ }^{108}$ as the former are subject to the rules of procedure as well as the precepts governing the profession. The practice in Ethiopia does not take this distinction into account as the profession of the agent is the most important factor rather than the task to be carried out.

\section{Effectiveness}

A power of attorney may be executed with a view to make it effective immediately. A power of attorney does not, however, necessarily produce legal effect immediately. As has been spelt out above, it presupposes a contractual relationship between the delegator and the delegate. If it follows a prior agreement of the parties, the power of attorney produces effect when it is tendered to the agent. Possibly, it may be authenticated without the knowledge of the person authorized therein. In such a case, even though it is a legal document, it is not useful until it is handed over to the agent. Though it does not legally have the same effect as regards effectiveness of the document, the principal may keep the power of attorney and delay its utilization and hence effectiveness.

Acceptance is also another requirement as it is drawn up without the assent of the agent. Acceptance may be express or tacit. It is tacit, when the person appointed begins to exercise authority or performing duties as an agent or by any other assertion or conduct indicating acceptance. ${ }^{109}$ As it is not an instrument governing the internal relationship, its value depends on its use in the relationship between the principal and third parties. Short of that it is a piece of paper producing no effect.

Apart from the agreement of the parties which is a factor for instant effectiveness of a power of attorney, stipulations may determine its effectiveness. As discussed above, a power of attorney may be springing or contingent depending on whether it produces effect immediately or upon occurrence of a certain event. The principal may provide (in the power of attorney) that it becomes effective at a certain future date or upon occurrence of a future event. Such delegation needs activation so that it becomes effective. A principal may also appoint an alternate agent in case the agent is

\footnotetext{
${ }^{107}$ Floyd R. Mechem (1952), Outlines of the Law of Agency, Chicago, p. 47

108 Warren A. Seavey (1964), Handbook of Law of Agency, St. Paul, Minn. West Publishing Co., p. 55

${ }^{109}$ Civil Code, supra note 4, Art. 2201
} 
unwilling or unable to act on behalf of the principal. The power of the alternate agent becomes effective when the condition (unwillingness or inability of the agent) transpires.

The other issue relates to the length of time a power of attorney remains effective after it has been executed. In Ethiopia, the age of a document does not affect its validity and it is unusual to set time limit to the instrument in it. ${ }^{110}$ But, questions may arise regarding the validity of the document because of change of circumstances over time which may affect it such as death or incapacity of the principal or even revocation. In practice, it is not uncommon to witness certification of a power of attorney by the notary which authenticated it. ${ }^{111}$ Some jurisdictions explicitly specify the duration of a power of attorney by indicating conditions which terminate it. For instance, in some jurisdictions a power of attorney remains in force until written notice of revocation by the principal, or of the renunciation thereof by the agent, or may terminate if either the agent or the principal dies or becomes incapable. ${ }^{112}$

Once it becomes effective, third parties are duty bound to accept a power of attorney. The law does not regulate the failure to accept or delay in acceptance. As stated above, some banks do not accept a power of attorney outright and they send it the notary office to verify its genuineness. The delay may have financial and other consequences, and it compels one to raise the query whether such actions are justified. The consequence of acceptance in good faith of a power of attorney seems to be the source of fretfulness of third parties.

Wrongful refusal to accept or acknowledge a power of attorney validly executed entails liability. In some legal systems, provisions are incorporated in the law which protects third parties who accept a power of attorney in good faith even if subsequently it has been found out that it is not genuine. Thus, a person who accepts in good faith a power of attorney without actual

110 There are legal systems which limit the validity of a power of attorney. Armenia sets a maximum of three years, See Art. 322 of the Civil Code of the Republic of Armenia, available at https://www.cba.am/EN/lalaws/CivilCode_eng.pdf

${ }^{111}$ Some banks send a copy of a power of attorney for certification contrary to their duty to accept an official document. In fact, even this may clear some of the doubts which basically can be resolved by improving the security feature of the document. Power of attorney is obviously one of the documents exposed for forgery and the need for introducing mechanisms that improve reliability is long overdue.

112 See for instance Malaysia Power of Attorney Act of 1949, Incorporating Amendment up to January 1, 2006, Article 6(1) available at https://simplymalaysia.files.wordpress.com/2011/10/act-424-power-of-attorneyact.pdf 
knowledge that the signature is not genuine or a latent defect is protected by the law in that he can invoke the same protection extended to a third party who relied on a genuine power of attorney. ${ }^{113}$

An authenticated document is conclusive evidence with regard to its contents and in proceedings it can be challenged only with the permission of the court for good cause. ${ }^{114}$ The probative effect is given emphasis which is accentuated in the law. This precept was reiterated in a case ${ }^{115}$ in which the court ruled that the bank may rely on the document by looking at the seal and signature affixed on it. In this case, forensic investigation report confirmed that the signature on the power of attorney is not that of the respondent. Such a notarized deed cannot be impugned without leave of the court. The question that arises under the circumstances is the standard of care expected of a third party who relies on the document.

Obviously, it cannot be the kind of investigation that is carried out by a forensic expert with the assistance of devices. If so, there is no reason to order investigation of signature on the instrument as it changes nothing whatever the outcome of the investigation. One has to corroborate whether the document prima facie shows anything that someone has tampered with it compromising its reliability or causing suspicion on the authenticity of the document. In the case indicated above (Development Bank of Ethiopia versus $W / r o$ Alemenesh Haile) the Cassation Division duly confirmed the appellate court's decision which stated that it is not only the forensic investigation report but also the instrument itself which indicate the evidence that it is tampered with and its content was suspicious.

The latter cannot be brushed aside as the instrument cannot be relied on even by the standard introduced by the Cassation Division. If it can be gathered from the document itself that it was tampered with as established by the appellate court, the issue should have been whether, it was appropriate for the bank to accept the power of attorney and advance the loan. As the Cassation Division accepts the facts ascertained by lower courts, the consequence is that the bank could not be in good faith to accept the power of attorney which on the face of it was not trustworthy.

\footnotetext{
${ }^{113}$ See for instance Uniform Power of Attorney Act, Section 119(b), National Conference of Commissioners on Uniform State Laws (2008).

${ }_{114}$ Proc. No. 922/2015, supra note 8, Article 23.

${ }^{115}$ Development Bank of Ethiopia versus W/ro Alemenesh Haile, Vol. 5 File No. 20890 decided on 10/11/1999, Federal Supreme Court Cassation Decisions, vol. 5, (2001 E.C), p. 12.
} 


\section{Conclusion}

In the ordinary course of things juridical acts are performed by the person who creates, modifies and terminates his obligations and rights. But, this is not always the case. Delegation is a necessary component of modern life. Indeed, business and administration of entities become impossible without some sort or degree of delegation of authority. It is usually through a power of attorney that delegation is realized. Significance of the device necessitates a law governing power of attorney considering its social and economic importance. We have seen above that there are questions which the existing law does not answer. Other jurisdictions dealt with the issues raised above by enacting a special legislation devoted to power of attorney.

A special law enables the legislator to address many of the issues raised above enhancing reliability of the instrument and maximizing its utilization. The lack of clarity on the form of power of attorney will remain a challenge in every area of human life whenever authentication is not compatible with the need of a particular sector or situation. The blanket provision in the Proclamation does not seem to recognize an exception and the message seems to be that all documents must be authenticated so long as they grant power to another. Other jurisdictions avoid such blanket restriction by excluding some transaction or expressly specifying the acts which require an authenticated power of attorney. Definition of the term and determining its scope extenuate the challenge in this regard.

The application of the law is principally shaped by the dictation of the notaries both in the form of the advice to its contents or the guideline adopted by the Agency. Although the Agency has attempted to fill gaps that are observed in the course of authenticating power of attorney (by issuing a procedural manual), there are still many issues that are being resolved case by case. Handling matters in such sporadic approaches affects substantive rights of citizens, and should not be left to the discretion of officers of the Agency. It is, therefore, necessary to have a separate power of attorney law, or there is the need to elaborate the existing laws with a view to addressing the gaps examined above. 